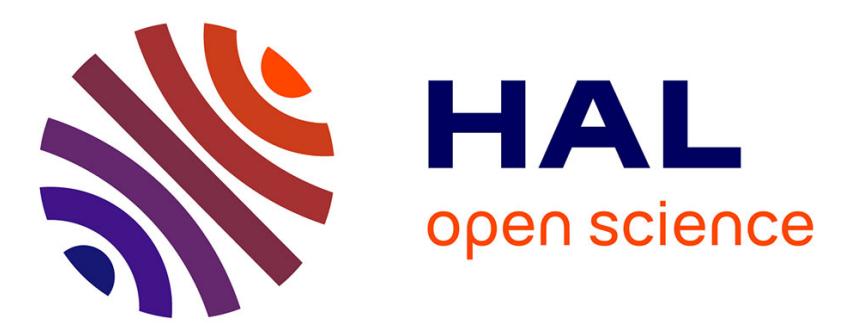

\title{
How to perform non-racism? Colorblind speech norms and race-conscious policies among French security personnel
}

François Bonnet

\section{- To cite this version:}

François Bonnet. How to perform non-racism? Colorblind speech norms and race-conscious policies among French security personnel. Journal of Ethnic and Migration Studies, 2014, 40 (8), pp.1275-1294. 10.1080/1369183X.2013.847358 . halshs-01060571

\section{HAL Id: halshs-01060571 https://shs.hal.science/halshs-01060571}

Submitted on 3 Feb 2015

HAL is a multi-disciplinary open access archive for the deposit and dissemination of scientific research documents, whether they are published or not. The documents may come from teaching and research institutions in France or abroad, or from public or private research centers.
L'archive ouverte pluridisciplinaire HAL, est destinée au dépôt et à la diffusion de documents scientifiques de niveau recherche, publiés ou non, émanant des établissements d'enseignement et de recherche français ou étrangers, des laboratoires publics ou privés. 


\title{
How to perform non-racism? Colorblind speech norms and race-conscious policies among French security personnel
}

Francois Bonnet

Pacte, CNRS - University of Grenoble

\begin{abstract}
How do individuals and organisations anticipate or deflect allegations of racism? This problem is especially sensitive in the context of crime control. There are two strategies to perform non-racism: colorblind and race-conscious. This article is about how French police officers and security guards perform 'not being racist', based on an analysis of the discourse and policies of 60 respondents in a shopping mall and a railway station. France promotes an ostensibly colorblind approach to being not racist, urging its citizens to avoid using racial categories. How do security people manage to perform non-racism when the majority of their clients are minority youth? The main finding is that while respondents display a strong command of colorblind speech norms (to perform non-racism), the security policy of the shopping mall is equally strongly race-conscious (also to perform non-racism).
\end{abstract}

Contact information frabonnet@gmail.com

This paper has been presented at the 2011 ASA conference in Las Vegas and the 2013 CES conference in Amsterdam. It has been financially supported by the SPACECONTROL project (ANR $n^{0}$ ANR-10-ESVS-001-01), at Maison européenne des sciences de l'homme et de la société (MESHS - USR 3158) and by the Dynamics of Citizenship and Culture program group at the University of Amsterdam. I am also grateful for the feedback and comments from Frank Bovenkerk, Rogers Brubaker, Naïma Makri, Ana Miškovska Kajevska, Mary Pattillo, Maria Reimann, Francesco Ragazzi, Eva Rosen, Clément Théry, Sudhir Venkatesh and Sharon Zukin. 


\section{How to perform non-racism? Colorblind speech norms and race-conscious policies among French security personnel}

How do individuals and organisations anticipate or deflect allegations of racism? This problem is especially sensitive in the context of crime control (Bowling and Foster 2002, Fassin 2011, Tonry 1995, Unnever and Gabbidon 2011, Weitzer and Tuch 2005). The problem I am interested in is the need for security personnel and organisations to perform non-racism.

Recent research on the lived experience and the interactional aspects of race is helping us to uncover the structure of racist and discriminatory practices (for instance Anderson 2012, Essed 1991, Lamont and Aksartova 2002, Lamont and Fleming 2005, May 2001, McDermott 2006 and Pollock 2004). To contribute to this body of work, I focus on the everyday work involved in presenting oneself as "not racist" and examine the strategies by which people try to avoid or deflect a potential accusation of racism. There are two strategies to perform "not being racist": the colorblind approach and the race-conscious approach (D.Fassin 2006, Lamont and Fleming 2005). These strategies are mutually contradictory. How do security personnel-police officers and security guards - manage to perform nonracism when they concentrate their efforts on minority youths $\mathrm{s}^{\mathrm{i}}$ ?

To investigate this question, I interviewed 60 people in a shopping mall and a train station in France, a country that embodies the colorblind model on race relations. Malls and stations are places where people gather and move through fairly continuously, and are ostensibly filled with strangers. These are spaces where minority youth are perceived as posing all sorts of problems from shoplifting to vandalism and disorder. In the shopping mall, a riot involving mostly minority youth and happening on the last day of Ramadan had occurred a few years ago, heightening the concern over racism. I conducted fieldwork on law enforcement and private security, focusing on the everyday work of security guards and police officers and on the development of security policies by the management.

What is especially interesting with suspicions and accusations of racism is that they can affect individuals as well as organisations. In effect, this study is about the discursive strategies of non-racism-how people manage implicit or potential accusations of racism in the course of interviews; and about the policies of nonracism-how organisations perform non-racism through security policies they implement.

Unsurprisingly, security personnel are particularly concerned with performing non-racism: their legitimacy depends on it. The counterintuitive finding is that while respondents adopt the colorblind strategy to perform non-racism during interviews, in practice the mall's security team has to implement a race-conscious security policy. Indeed, they have little choice. Since the riot, this security team has been charged with implementing a security policy that would not incite further rioting. Store managers actively hired non-white security guards, typically Arab and Black, to deal with minority shoplifters and troublemakers, working on the assumption that racial familiarity would lead to more effective policing by deflecting the accusations of racism. My findings enable me to reflect here on the 
relevance of national models of race relations for making sense of local situations, and on what is tacitly defined as non-racist in a given situation.

\section{Performing non-racism}

Why would people have to perform non-racism?

In contemporary public space and social science, racism is under a strong and near-universal disapproval: very few people claim to be racist. For example, in the past twenty years, public opinion research in the United States has found fewer respondents willing to endorse racist views (Blauner 1989, DiMaggio, Evans and Bryson 1996, Schuman et al. 1997). In many Western democracies, overt racist speech is publicly reviled and there are legal statutes criminalising racist speech and discrimination, or aggravating punishment for hate crimes (see Bleich 2011 for a comparative analysis of the regulation of racist speech). Even extreme-right political parties, whose appeal largely rests on racial resentment, vehemently object to being labelled as racist (Bastenier 2004:14). In everyday life, this translates into a social world where people do not want to sound racist: "Many of us exhibit particular worries about being 'racist' with our very language" (Pollock 2004:1).

Because of the changing desirability of racism, people may want to avoid an accusation of racism; they may have to "perform non-racism". By "non-racism", I mean "the fact of not being racist", or "the contrary of being racist". If something or someone may be racist, then something else or someone else may "not be racist". For instance, most public figures are concerned with "not appearing racist"-with performing non-racism.

Note the difference between non-racism and anti-racism. Anti-racism is a form of activism for social and racial justice, while performing non-racism only refers to "the presentation of self in everyday life". This idea of performance refers to what people (or organisations) want to ostensibly communicate. Performing non-racism does not mean that one is not racist. One can publicly perform non-racism while privately harbouring racist thoughts or covertly engaging in racial discrimination and hateful acts. As Goffman (1959:23-25) argues, performances may or may not be sincere. What matters for this article are the norms and power relations that constrain people to perform non-racism, and not the sincerity of their performance, nor what is "inside people's head" (Eliasoph 1996: 265).

This conception is at odds with two distinct strands among the vast literature on racism.

\section{Performances of non-racism: beyond what people "really" think}

The first strand comes from structural conceptions in the sociology of racism (Bonilla-Silva 1997, 2004, 2006; Desmond and Emirbayer 2009). Within this framework, performances of non-racism are distractions for racially naïve sociologists (see for instance Bonilla-Silva 2002:62's critique). To explain the paradox of declining overt racism and persisting racial inequality, these authors argue that front stage civil race talk (professed tolerance) is a cover for backstage discrimination and "tolerance" for racial inequality. Racism exists to maintain and perpetuate whites' privileged position, and the "new racisms" (symbolic [Kinder 
and Sanders 1996, Kinder and Sears 1981], laissez-faire [Bobo, Kluegel and Smith 1997], colorblind [Bonilla-Silva 2006], two-faced [Picca and Feagin 2007]) are the best functional way of maintaining racial domination. This literature translates into research that aims at uncovering backstage racism behind front stage tolerance (Bell and Hartmann 2007, Bonilla-Silva 2002, Lewis, Chesler and Forman 2000, Myers and Williamson 2001, Zamudio and Rios 2006). From this perspective, performances of non-racism only make sense insofar as they reveal covert racism.

The second strand is the literature on discrimination (Pager and Shepherd 2008, Quillian 2006), which, remarkably, displays a lack of interest in the concept of racism, as if it was a less-than-scientific notion ${ }^{\text {ii }}$. By renouncing racism as a category of analysis because it is flawed, discrimination scholars prevent themselves from studying the everyday relevance of racism as a category of practice (for discussions of racism as a category of practice, see Wacquant 1997, Brubaker and Cooper 2000). Furthermore, like racism scholars, discrimination scholars share a concern with knowing what their subjects think "deep down"what would they say if it was not for the social desirability bias (Pager and Karafin 2009, Pager and Quillian 2005; on social desirability, see Krysan and Couper 2003 and Phillips and Clancy 1972). Discrimination scholars are thus looking for ways to "overcome" what they identify as a methodological obstacle. I, however, argue for studying social desirability in itself, as a relevant social phenomenon, because racism as a category of practice does matter in people's everyday lives.

What both perspectives overlook is how important it is for people and organisations to avoid an accusation of racism, i.e., to perform non-racism, and how this is performed.

\section{Colorblind vs. race conscious strategies for non-racism}

As mentioned previously, there are basically two strategies to perform nonracism: the colorblind (or universalist) strategy, and the race-conscious (differentialist) strategy (Brubaker 2001, D. Fassin 2006, E.Fassin 2006, Lamont and Aksartova 2002, Lamont and Fleming 2005). The colorblind approach consists of denying race altogether, on the ground that all humans belong to one race, and the race-conscious approach consists of recognising racial difference with the intention of remedying racial inequality. Although each of these strategies is perfectly coherent and has been endorsed by moral leaders and antiracist activists, they are contradictory. From the colorblind point of view, raceconscious perspectives are inherently racist, since they acknowledge differences based on race. Conversely, from the race-conscious point of view, colorblindness is a pretext to prevent the implementation of policies such as affirmative action that can achieve racial equality. Either position (colorblind or race conscious) that is non-racist in one country may be deemed racist in the other.

Whether one strategy or the other is valid varies in time and space: Bonnett (2006) has analyzed how anti-racism initiatives in Latin America were being "Americanized". The early Civil Rights Movement in the United States fought racism on a colorblind stance (Sears 1996). Today, colorblindness in the United States is often equated with neoconservative racism (Bonilla-Silva 2006, Winant 
2000, 2007). In France, colorblindness is the preferred non-racist ideology (Bird 2000, Bleich 2001, see also Keaton 2010 and Ndiaye 2008 for critical assessments). The variation in time and space of the types of non-racism has led to the conception that there are national models of race relations. It is, for instance, widely believed in the social sciences that France is exemplary of an idiosyncratic conception of citizenship, nationhood and immigrant integration. Brubaker's (1992) book on French and German conceptions of citizenship and Favell's (1988) on philosophies of integration in France and Britain have depicted quasi-ideal typical models of nationhood.

In many respects, France seems like an embodiment of colorblind non-racism. The French Constitution's first article states that "France (...) ensures the equality of all citizens before the law, without distinction of origin, race or religion". This makes it difficult for race-based affirmative action to be enforced, and for ethnic statistics to be collected: the French census is strictly colorblind. The colorblind discourse is especially meaningful in France in the context of the extermination of European Jews and post-war decolonisation (Bird 2000). The denial of the Holocaust and race-based hate speech are criminalised under French law (Bird 2000). Colorblindness is as much part of the French polity as secularism and many (not all) French anti-racists sincerely believe that ethnic statistics and affirmative action favour thinking in racialised terms, and therefore favour racism. France's emerging racial question is linked to postcolonial immigration. The two main immigrant groups are North Africans (also referred to as Arabs or Maghrebi), who mainly come from Algeria, Morocco and Tunisia, and SubSaharan Africans, mainly from francophone West Africa. Estimates (ethnic statistics being forbidden) suggest that there are around 3 million Arabs and 3 million Sub-Saharan Africans, roughly $10 \%$ of the nation's population (Tribalat 2004). There is widespread suspicion that non-whites endure socio-economic inequality, residential segregation and discrimination, especially in the criminal justice system (Body-Gendrot and Wihtol de Wenden 2003, Open Society Institute 2009, Pager 2008,), suggesting a trajectory of downward assimilation (Portes and Zhou 1993). Chronic urban riots in the banlieues over the last 30 years reinforce the idea of a French racial question (Lagrange 2006, Waddington, Jobard and King [ed.] 2009).

In short, France is a strategic case because its emerging racial question may challenge its colorblind ideals, and because national models need to be assessed from the bottom up. The research questions then are: How do security personnel perform non-racism when they concentrate their efforts on minority youth? What strategies do they use to avoid accusations of racism? Are these strategies predefined by established cultural models?

\section{Research design}

To explore these questions, this article draws on a qualitative study of law enforcement and private security in two urban spaces, a shopping mall and a railway station, in Lyon, France's second urban area (1.4 million inhabitants).

\section{A qualitative study of security in train stations and malls}

Railway stations and shopping malls are mass private properties where people come and go by the tens of thousands every day. Security and order are prime 
concerns for the management of these spaces, sharing similar concerns about the management of crowds.

The mall has a particular racial history that makes it a more sensitive space for the study of the performance of non-racism. During the 1990s, white middle classes perceived the shopping mall as declining in attractiveness, partly because it was old, and partly because of the increased presence of minority youth. The mall acquired a reputation for disorder and delinquency, which the mall's management responded to with a tougher security policy, based on the harassment of minority youth. The situation deteriorated until a full-scale riot erupted, on the last day of Ramadan (the month of prayer and fasting in Islam), resulting in nine people injured and fifteen arrests. The riot caused significant vandalism and looting, and further damaged the reputation of the mall. The station (which is near the mall) did not experience the riot with the same intensity, and its security actors are not as concerned with a riot as their colleagues from the mall (Bonnet 2009). In this article, therefore, I use the station as a counterpoint to the rather exceptional situation of the mall.

In the two spaces, I observed the interaction of security personnel and customers, including minority youth. As my familiarity with the spaces grew, I conducted 60 interviews with security guards, their various sponsors, and police officers:

- 28 interviews in the station: the station manager, 6 railway company employees (including 2 labour representatives); 1 social worker; 3 shopkeepers and 2 employees (including one labour representative); 2 police managers, 3 police officers; 2 security managers for the railway company and 8 security guards.

- 29 interviews in the mall: 6 managers or shopkeepers, 9 employees (including 2 labour representatives), the security manager of the mall, 3 security guards (including 2 labour representatives), 3 security managers; 1 police manager and 6 police officers.

- in addition, I interviewed the precinct commander, the alderman and a city official, both with responsibility for security.

Interviews ranged from 45 to 90 minutes and were transcribed and inductively coded (Glaser and Strauss 1967). The interviews questions were about the relations between private and public security, and interviews typically featured questions about the content of the respondents' daily work, their perception of security concerns, their perception of offenders, and the quality of their relations with other actors.

\section{Speech norms and actual policies}

Interviews revealed two types of performances of non-racism, both in discourse (how respondents talk about race-first empirical section) and policies (what security people are told to do about minority youth, and what they actually dosecond empirical section). Both sections are based on the same research material (interviews), but I analyze these interviews differently.

The first empirical section of the article is about discourse and speech norms. Like other scholars (e.g., Eliasoph 1990, 1999; Young 2004), I use the tension that animates conversations on race as research material; it is the interaction between 
respondents and me which constitutes the data. Because I am a French white male, at that time a $\mathrm{PhD}$ candidate in sociology from an elite school, I unmistakably embodied dominant norms. I use threats to the interaction order (Goffman 1983) during the interview as a tool to reveal speech norms. I am not making claims about the intentions of the speaker (whether she means to convey racial undertones or not). The problem for French respondents is that straightforward designations of minorities sound racist, regardless of the intentions of the speaker. In this article, I do not make claims about the racist meaning of racial undertones because it is not important to my argument. What matters is that respondents have to perform not being racist, and how they do it.

The second empirical section of the article is about the security policy designed by the management of the shopping mall (and implemented by its security guards). Studying actual policies is necessary, given the sometimes wide discrepancy between discourses and practices (Pager and Quillian 2005). I focus on the shopping mall's security policy (and deliberately set the station aside) because of the consequences of the race riot and its strategic relevance for my argument about the performance of non-racism. I have researched the mall's security policy through the 29 interviews mentioned before, confronting multiple accounts of the many actors involved, in the tradition of policy case studies; reliability is enhanced by way of triangulation (Gerring 2004, Lin 1998). I have done non-participant observation of the interactions in the mall. As I will develop in the empirical section, the policy consists of ethnic hiring and mediation towards minority youth. Ethnic hiring has obvious consequences, and the reality of the policy of mediation is confirmed by its most bitter opponents-police officers and petty shopkeepers.

To summarize: in the first section about discourse, I study respondents performing non-racism to me, the then graduate student, during the interview interaction, both in the station and the mall. In the second section about policy, I study respondents in the mall performing non-racism to potentially rioting minority youth, as part of their security policy. I do so to show that in the mall, the same people use contradictory strategies to perform non-racism in discourse and in practice. In the second section, I use the station as a silent counterpoint to highlight the contingent aspect of the mall's peculiar security policy.

\section{Race muted: colorblind speech norms governing interviews}

Whether true or false, there is a consensus in the mall and in the train station among respondents (shopkeepers, employees or security personnel) that the main troublemakers are minority youth from disadvantaged neighbourhoods-mostly (not all) Arabs. As a consequence of colorblind speech norms, French respondents cannot use straightforward words for minorities such as "Arabs" or "NorthAfricans". This is not specific to the people in my sample. There is a socialscientific literature about how French institutions manage to deal with race without naming it (Fassin and Fassin [ed.] 2006). Urban policy has, for instance, been analyzed as affirmative action in disguise, with space serving as a proxy for race (Doytcheva 2007, Kirszbaum 2004). "Urban violence" in the French media really means "minority crime" or "race riot" (Macé 1999). In this section, I document how respondents perform non-racism during interviews by remaining 
"colormute" (Pollock 2004) or by carefully managing the stigma that comes with breaking colorblind speech norms.

\section{"Colormute" respondents and the art of suggesting race}

The main route to colormuteness is the use of words that are semantically void of racial meaning. To refer to minority youth, many respondents use "youth", a short form of "urban youth". Although these euphemisms can denote other social attributes, like class and space (see Kirschenmann and Neckerman 1991), a greater sensitivity arises around race.

Researcher: What is your main security problem?

Security manager: Gangs of youth. My top priority is to deter those youth that come in groups. So, when they come, we know them. I have made a priority of fighting against those youth. (...) This is a private area, open to the public. We intend on staying in charge of our own territory.

Store manager: Gatherings are not forbidden, if they are chatting together, it's no big deal, but provocation is a problem. Sometimes we have gangs running across the store laughing. We don't want to run any anti-youth or racist policy. I don't want this interview to go that way but we are working for the comfort of our customers.

(Security manager, white male, and store manager, white female, department store, mall)

In this exchange, neither party is saying anything explicit about race. The security manager is concerned by "gangs of youth", and her boss, the general manager, is merely concerned about "comfort" in the store. But the manager takes pains to tell me that she is not racist, indicating her awareness that any comment about gangs of youth might be taken as such. In this context, suggesting race while performing non-racism requires interactional skills. Skilled respondents use coded innuendoes to suggest race in the most allusive ways. These respondents may for instance allude to the clothing style of minority youth. Expensive track pants, such as Lacoste's, become a metonymy for Arab.

If you want to see problems, go to Lacoste. (Saleswoman 1, luxury superstore, white female, mall)

The multiple mentions of Lacoste are not random. In France, the Lacoste brand is widely associated with minority youth, who often dress in designer brand track pants (Pringle 2000). Such expensive outfits seem unaffordable to poor immigrants, and many French people believe that minority youth acquire them illegally.

Researcher: What kinds of goods are stolen?

Respondent: There is a targeted demand for certain products, men products, brands, perfumes.

Researcher: Which brands?

Respondent: Lacoste [she stares at me in silence] (Assistant manager, luxury superstore, white female, mall) 
By referring to Lacoste, respondents are able to suggest race without saying race, and to refer to both race and crime without threatening colorblind speech norms. The ambiguity about racial undertones allows for plausible deniability. To reduce the ambiguity and abide more safely by colorblind speech norms, some respondents use replacement words that are less directly allusive to race, such as "fools", "tough guys with an urban style", "kids", "little morons". Again, the point is not that, in fact (inside their head), respondents are racist (or not). I document how respondents perform non-racism in a context of colorblind speech norms. Paradoxically, in the interview setting, the most neutral words ineluctably acquire a racial undertone.

\section{Managing the stigma of a potential accusation of racism}

Because of colorblind speech norms, it is difficult in France to mean race (to carry racial undertones) without sounding racist. The context of crime control means that racial undertones - already inappropriate by colorblind norms - are even more likely to be suspected of racism. Security guards and police officers in France are fully aware that their focus on minority youth fuels accusations of racism and discriminatory practices.

In private security, we have two reputations which are negative: we are bullies and even better, racists (Security manager, leisure store, mall)

Yet, some respondents, pressed with questions, cannot (or do not want to) remain colormute. How do police officers and security guards perform non-racism when they have to explicitly designate their main target?

The first solution to perform non-racism while engaging in explicit race talk is contrition, the expression of sorrow and repentance, which is a way for respondents to signal that they respect, understand, and usually abide by, the dominant norms of non-racism (since racial categorization is already a form of racism in France). In numerous instances, respondents become demonstrably apologetic in their explanations of talking directly about race, anxious that they are violating speech norms. The point is not whether they are truthful or sincere, but how they speak about race.

Researcher: Who are the offenders?

Respondent: [Hesitant] They are young...yes young, but in [the train station] since I've been here, I haven't had much to do with delinquents, there are more problems like infringements of SNCF rules; when they don't have their train ticket, identity papers, stuff like that, yes, they are mostly young people... [short pause] er...[lowers his voice] North-Africans. So I am telling you the truth as it is, it's not...er... (Security guard 2, white male, station)

Contrition ostensibly communicates that respondents are aware of colorblind speech norms and of the gravity of their offense. Contrite respondents perform non-racism by showing deference to norms: they seem to check that I am aware of their acceptance of conventional speech norms. Contrition thus actually reveals that colorblind speech norms are norms. 
A second solution for interviewees is to deflect a potential accusation of racism by engaging in defensive assertiveness. In this speech act, respondents violate colorblind norms in ways that communicate an awareness of said norms and a rationale for the violation. It is as if they were saying to me, "I know that you suspect me of racism, but I'll try to convince you that I am just doing what my job asks of me". Assertive interviewees act as if displaying contrition would be an implicit admission of their guilt, and they take on a more direct approach by trying to reframe the terms of the debate.

You want me to be honest with you? You really want me to be honest with you? Objectively speaking? 90\% of my clients are North-Africans or African youth. It won't please everybody but sadly, it's the truth. 90\% of my clients. The 10 remaining percent... It's a fact, my clients, I am not going for them, they are coming to me [awkward laughs].

(Security guard 1, white male, station)

The rationale of defensive assertiveness is that the over-criminality of minority youth is a "sad truth" that cannot be denied and that security people have a functional requirement to engage in what may appear as racist behaviour. Interestingly, a minority respondent - therefore less in need of performing nonracism-also used defensive assertiveness to speak about disproportionate minority delinquency. This Arab security guard walked me out of the mall after an interview. He put his hand on my shoulder and lowered his voice:

I'm going to speak frankly, I am a Maghrebi. The youth, I tell them: "who's screwing around, it's us, who spits on the sidewalk and can't behave in the street, it's us. Yet, at home, in Algeria, in Morocco, you don't act like that! (Security guard 5, Arab guard, mall)

It is remarkable that even minority respondents use oratory precautions to violate colorblind speech norms. Assertive respondents act as if they want to convince that they are non-racist, instead of apologizing for saying something that might offend speech norms, as contrite respondents do. In short, the interviews force respondents into tricky performances of non-racism who reveal colorblind speech norms.

\section{Deviance to speech norms}

Not all respondents abide by colorblind speech norms. One main reason for this is the evolution of the relationship between the sociologist and the respondent. Most of the explicit quotes in this article are the result of a progression in the interview. But some respondents are truly deviant. The following excerpt is from an interview with a white police officer in his fifties who speaks about the criminal activity in the mall. After discovering by chance that he and I are distant relatives, the respondent spoke as if speech norms do not apply any more.

The problem, it's always the same youth, the same gangs we get, I won't say who, I'd be called a racist, they come to steal, to drink, to fuck with the population. Well, back there in Italy, they can hire as many security guards as they please, they do have [racial slur for Arabs], they do have Romanians, and also because Italians are thieves. It depends on race! We are not allowed to say it, but it depends on race. Durand, Dupont, Bonnet [French-sounding names], we get one maybe twice a week, the Benhamou, the Karim, the Zoulou 
[foreign-sounding names] you arrest 50 of them. Delinquency, it's 95\% from Maghreb [North Africa]. Ah, that's France, you can't say anything... They are promoting Jean-Marie [extreme-right leader Jean Marie Le Pen]. The énarques [the liberal elite], these dickheads, they tell you that everything's fine, but people are not dumb, when they steal your bike, you know it's them, they spit at you, they call you "son of a bitch", so obviously, people arrive at the voting booth, they can vote right, they can vote left, and they vote Jean-Marie. (Police officer 3 , white male, mall)

It is worth noting that this quote is unique in my sample (his colleagues had warned me that he was a fringe character). What is nonetheless meaningful is that the deviant respondent makes speech norms explicit ("I won't say who, I'd be called a racist", "we are not allowed to say it"). Most of his argument belongs to the register of defensive assertiveness. He implicitly presents himself as an extreme-right voter whose electoral behaviour is explained by the over-criminality of minority youth and the speech norms preventing discourse about minority crime (and not by an irrational hatred of minority): in effect, he communicates "I violate speech norms, but not out of racism". It is striking that even he attempts to perform non-racism. In the next section, I show how non-racism also has to be performed in policy-not just interviews.

\section{Race enacted: strategically race-conscious security policies}

To study policy, the mall's case is of special relevance because of its racial history. The mall's management and its security team have to police the premises because crime and disorder threaten business' profitability (Lee 2002). As a consequence of commercial decline and racial tensions that culminated in a race riot, the management was changed and supervised a \$30-million dollars renovation of the mall. The new management has implemented a security policy which does not derive from a change in law (Dobbin and Sutton 1998) nor is it due to the rise of human resources professionals (Dobbin 2001-2002), rather it stems from the realization that performing non-racism is key to avoiding another riot.

Security personnel have to handle two types of criminal problems in the mall: shoplifting and disorder (Bonnet 2008 and 2008b). In my sample, most respondents perceive Arab youth as mainly responsible for most of the petty shoplifting and for disorderly conduct (loud arguments, exuberant behaviours, rude comments towards teenage girls who object to being sexually insulted). Security guards need to control shoplifting and to limit disorderly behaviours, so that customers do not perceive the mall as unwelcoming and/or an "Arab territory". But they must do so in ways that appear non-racist, to avoid another riot.

To protect themselves against potential accusations of racism, the mall's management and the stores have hired security guards with minority backgrounds. In the communal parts of the mall, which are run by the mall's management, most of the security guards are Arab. In the stores, which pay rent to the mall and are subjected to problems of shoplifting, guards typically are Black. The rationale of the policy is the following: since minority teenagers are involved in a significant amount of shoplifting and in the vast majority of disorders, security guards need 
to focus their attention on minority teenagers, and, if security guards were white, minority teenagers could accuse them of being racist. However, since guards also are minority, the accusation becomes irrelevant.

For one thing, you can't say they [minority guards] are racist. (Security manager, white male, mall)

Again my point is not to assess the truth of respondents' folk theories, but to examine its logic and effects. Why are guards Arab in communal parts and Black in the stores? In communal parts, the shopping mall's management wants to reduce tensions between the security team and teenagers, and to prevent further disturbances. Arab security guards are hired from the same housing projects where teenagers are supposedly from. Cultural proximity between teenagers and guards allegedly allows for better communication.

And then, they know the kids, they have the same language. It's better than if someone else was taking care of the problems. (Security manager, white male, mall)

The explicit mission of Arab guards is to ensure that relations between storekeepers and teenagers do not escalate. They must prevent conflicts, keep situations under control and make sure that both side's feelings are spared. Their role is similar to the Black employees of Jewish-owned stores in African American neighbourhoods: they act as "cultural brokers" Lee (2002:89). To avoid public arguments and volatile scenes, security guards are instructed to bring turbulent youth out, into the service corridors, outside public view. There, the guards call the mediator - an older (Arab) guard dressed up in a suit as opposed to an uniform-who specializes in talking youth into calming down and even apologizing to the people they wronged. This occasionally creates tensions with shopkeepers who cannot hire their own guards, and have to rely on the mall's.

There are these hoodlums ${ }^{i i i}$ who get caught, who have been shoplifting, and when the mall security guards arrive, they greet them by kissing them on the cheek to smooth things over (...) Once, a saleswoman at a women's clothing store up there, I'm not going to say which one, she had some female shoplifters, she got slapped a few times, and when the guard arrived, he kissed her [the shoplifter] on the cheek, he [the guard] spoke Arabic with her [the shoplifter]; she [the saleswoman] had been sent the guard from the Such-and-such family. It's unbelievable, if that happened to me, I'd punch the guy immediately! One day the whole thing will blow up because shopkeepers are sick of it. (...) In our stores we've never had too many problems, it's just guys in the store, there is never any conflict. But in womens' stores, they can't do much about it, and if the security guard starts to speak Arabic... or greet the shoplifter with a kiss hello... (Manager of a small shop, white male, mall)

These tensions demonstrate the reality of the policy of appeasement towards minority youth: small shopkeepers expect a kind of support from the mall's guards that is very different from the support they actually get. Shopkeepers want aggressive policing from the guards, but guards have been instructed by the mall's management to avoid the type of aggressive policing that eventually leads to riots. In fact, managers cite the lack of rioting by Arab youth in the past decade as direct evidence of their non-racism. 
Within the bigger stores, the purpose of security is to prevent thefts and expel troublemakers. Security guards in the stores have a more coercive role than in the communal parts: it is not so much about negotiating with troublesome teenagers than about deterring arrested thieves from making scenes. Most guards in the stores are Black. Experience seems to have taught private security companies' managers and store managers that white guards do not intimidate young Arab, while Blacks have a reputation that allows them to fulfil a dissuasive role, so they are mainly hired for the heavier policing (corroborated by Hug 2000; see Jackson 2006 about the exoticization of racialised masculinity). The guards' Blackness is simultaneously a solution to the problem of projecting a credible threat of coercion towards Arab youth and to the problem of performing a non-racist security policy.

In the stores they are Black; I was told "I send you Blacks; they scare Arabs". Security guards-the people they calm down, they are often Arabs. My boss told me "Arabs fear Black people". (...) The fact is also that Blacks are well-built, they are impressive, they are calm, and they are not French [white]. (Assistant general manager, sports superstore A, white male, mall)

From an ethnomethodological point of view, these practices operate under the tacit assumption that minority guards are ontologically immune to an accusation of racism, that only whites can be racists and/or engage in racial discriminations. A focused study such as this cannot tell whether the mall is the norm or the exception in its strategic ethnic hiring practices. In the case of the railway station nearby, however, there is no evidence of such policies, suggesting that the choice and implementation of a policy depends on local context and contingent factors. Race-conscious security policies certainly exist elsewhere in colorblind France: one of the respondents, a movie theater manager who has worked in Paris in the past, recalled similar matching strategies.

It depends on who the customers are, here we don't have too many Black people. In the $13^{\text {th }}$ district of Paris, there is a lot of Asians, so they have Asian guards, it's simpler. They communicate more easily, they understand each other, they speak in their language, it's in their own culture. In Cergy, at Les Halles, black guards, they didn't do the trick. There was a bad feeling with the customers, it was a problem. At Les Halles, it was the Eastern Europeans [guards] who did well. It depends on the place, there is a category that works better. (Manager, movie theater, white male, mall)

Such practices are interesting for they illustrate the discrepancy between raceconscious policies and colorblind speech norms. While interviewees have to speak colorblind to perform 'not being racist' in their interaction with me, they also have to implement a race-conscious security policy, precisely also to perform 'not being racist' in the everyday interactions that occur in the mall between the security team and the minority teenagers. This race-conscious security policy stems directly from the mall's management determination to avoid further rioting, and is consonant with similar efforts of ethnic hiring in law enforcement undertaken in the United States after race riots (Sabbagh 2011, p. 111-113; Skrentny 1996). Following Ward (2006:69)'s conceptual framework, the absence 
of riots in the mall suggests that ethnic hiring among the private security workforce affects both the substance of policing and its symbolism. This is a significant result (albeit restricted to this case), since research on the effects of a diverse workforce in the criminal justice system tends to find little tangible consequence to diversity (Farrell, Ward and Bourreau 2009, Ward 2006).

\section{Conclusion}

How to perform not being racist? I have argued that the exact same people resort to symmetrically contradictory strategies: the security guards of the shopping mall have to speak colorblind to perform non-racism in their interaction with me, but they have to implement a race-conscious security policy, precisely also to perform non-racism in the everyday interactions with minority youth, and all this in a colorblind country. This finding raises several concluding remarks.

An analysis which aimed to assess how "racist" the mall's security personnel are would miss the point on the local dynamics of race relations. The concern over performing non-racism is more than just a way of covering up for inner racism: it may shape policies. Racism is a powerful negative label, for those who design the policy and those who implement it. Respondents work hard, both in speech and in practice, to avoid that label. This result challenges racism research that assumes racist backstage attitudes or behaviour behind front stage tolerance. Even respondents who harbour private racist attitudes have to implement a policy that performs non-racism.

This result does not apply for the case of the railway station, where respondents "only" have to perform non-racism in discourse. Clearly, the historical context of the mall-the race riot-is a key factor for the race-conscious security policy. This highlights that local context matters. The discrepancies between the station and the mall on the one hand, and between colorblind speech norms and raceconscious policies in the mall on the other hand, suggest that a national colorblind ideology does not translate into a world where racial cognitions have been erased from people's mind. Race is definitely a category of practice, a category most French people use in their making sense of the social world. A national colorblind model does not prevent people from engaging into race-conscious practices. The local definition of non-racism does not derive from national models. This has implications for the generalizability of the findings. Whether or not people and organizations have to perform non-racism, and how they do it, should not be inferred from national models, but assessed in local settings.

Regarding the matter of how non-racism is defined, it seems important to point out its interactional component. We have seen that speech norms are not about what can be said (in the abstract), but about to whom it is said. When an interview begins as a conversation between strangers, slurs are offensive. A few minutes later, when the interview interaction is redefined as a casual chat among acquaintances, the slurs may lose their offensiveness for the participants. Speech norms should not be analyzed in terms of political correctness (as Pager and Karafin 2009 and Pager and Quillian 2005 do) because nothing is intrinsically "politically incorrect": the violation of speech norms is interactional in nature. "Political correctness" essentially is a category of practice; it is a loose, constantly 
redefined label; to use it as a category of scientific analysis is to be blind to the "situatedness of race talk" (Pollock 2004).

More importantly, non-racism is also defined in the daily interactions between law enforcement and private security and minority. To avoid damaging conflict, security personnel have to successfully perform non-racism to minority teenagers. In the absence of institutional channels, youth ultimately decide by rioting or not whether the performance is successful or not. In practice, security guards have to take into account the teenagers' tacit definition of what is a non-racist policing. The implementation of a race-conscious policy informs us on the tacit drawing of racism's boundaries in the shopping centre: white guards arresting minority teenagers falls inside these boundaries (it is "racist"), while minority guards managing minority teenagers remains outside (it is "non-racist"). The policy's race-conscious dimension shows that rather than deriving from the national model of non-racism, it derives from an empirical, bottom-up, practical understanding of the youth's tacit definition of non-racism. Of course, there can be many factors other than the mall's policy that explain the absence of rioting; but as long as the mall's management perceives its security policy as one of the relevant factors, the absence of rioting confirms the success of the policy's performance of nonracism.

\section{References}

Anderson, Elijah. 2012. The Cosmopolitan Canopy: Race and Civility in Everyday Life, New York: Norton

Adorno, Theodor W., E. Frenkel-Brunswik, D.J. Levinson, and R.N. Sanford. 1950. The Authoritarian Personality. Studies in Prejudice, New York: Harper and Row

Bastenier, Albert. 2004. Qu'est-ce qu'une société ethnique ? Ethnicité et racisme dans les sociétés européennes d'immigration, Paris : PUF, «Sociologie d'aujourd'hui »

Bell, Joyce M. and Douglas Hartmann. 2007. "Diversity in Everyday Discourse: The Cultural Ambiguities and Consequences of "Happy Talk", American Sociological Review, 72 (6), pp. 895-914

Bird, Karen L. 2000. "Racist Speech or Free Speech? A Comparison of the Law in France and the United States", Comparative Politics, 32 (4), pp $399-418$

Blauner, Robert A. 1989. Black Lives, White Lives: Three Decades of Race Relations in America. Berkeley: University of California Press

Bleich, Erik. 2001. “The French Model: Color-Blind Integration”, in J.D. Skrentny (ed.), Color Lines. Affirmative Action, Immigration, and Civil Rights Options for America, Chicago: University of Chicago Press, pp. 270-297

Bleich, Erik 2011. The Freedom to be Racist? How the United States and Europe Struggle to Preserve Freedom and Combat Racism, Oxford: Oxford University Press

Bobo L., J. Kluegel and R. Smith. 1997. "Laissez-faire racism: the crystallization of a kinder, gentler, antiBlack ideology", in S. Tuch and J. Martin 
(ed.), Racial Attitudes in the 1990's: Continuity and Change, Westport, Conn.: Praeger

Body-Gendrot, Sophie, and Wihtol de Wenden, Catherine. 2003. Police et discriminations raciales: le tabou français. Paris : Editions de l'Atelier.

Bonilla-Silva, Eduardo and Tyrone A. Forman. 2000. "'I Am Not a Racist But...': Mapping White College Students' Racial Ideology in the USA”, Discourse and Society, 11 (1), pp. 50-85

Bonilla-Silva, Eduardo. 1997. "Rethinking Racism: Toward a Structural Interpretation”, American Sociological Review, vol. 62, pp. 465-79

Bonilla-Silva, Eduardo. 2002. "The Linguistics of Color Blind Racism: How to Talk Nasty about Blacks without Sounding "Racist", Critical Sociology, 28 (1-2), pp. 41-64

Bonilla-Silva, Eduardo. 2004. "From Bi-Racial to Tri-Racial: Towards a New System of Racial Stratification in the USA", Ethnic and Racial Studies, 27 (6), pp. 931-950

Bonilla-Silva, Eduardo. 2006. Racism Without Racists (Second Edition), Lanham: Rowman and Littlefield

Bonnet François 2008, "Les effets pervers du partage de la sécurité. Polices publiques et privées dans une gare et un centre commercial", Sociologie du travail, 50 (4), pp. 505-520

Bonnet François 2008, "Un crime sans déviance : le vol en interne comme activité routinière", Revue française de sociologie, vol. 49, n², pp. 331-350

Bonnet François 2009, "Managing Marginality in Railway Stations: Beyond the Welfare and Social Control Debate", International Journal of Urban and Regional Research, 33 (4)

Bonnett, A. 2006. "The Americanisation of anti-racism? Global power and hegemony in ethnic equity". Journal of Ethnic and Migration Studies, 32(7), 1083-1103.

Bowling, Ben and Janet Foster. 2002. "Policing and the Police", in Mike Maguire, Rod Morgan, Robert Reiner (ed.), The Oxford Handbook of Criminology, Oxford : Oxford University Press, $3^{\text {rd }}$ edition, pp. 9801033

Brubaker, Rogers and Frederick Cooper. 2000. "Beyond Identity", Theory and Society, vol. 29, pp. 1-47

Brubaker, Rogers. 1992. Citizenship and Nationhood in France and Germany, Cambridge, Mass.: Harvard University Press, 1992

Brubaker, Rogers. 2001. "The return of assimilation? Changing perspectives on immigration and its sequels in France, Germany and the United States", Ethnic and Racial Studies, 24 (4), pp. 531-548

Desmond, Matthew and Mustapha Emirbayer. 2009. "What is Racial Domination?”, Du Bois Review, 6 (2), pp. 335-355 
DiMaggio, Paul, John H. Evans, and Bethany Bryson. 1996. "Have Americans' Social Attitudes Become More Polarized?", American Journal of Sociology, 102 (3), pp. 690-675

Dobbin, Frank, and John R. Sutton. 1998. "The Strength of a Weak State: The Rights Revolution and the Rise of Human Resources Management Divisions", American Journal of Sociology, 104 (2), 1998, pp. 441476

Dobbin, Frank. 2001-2002. "Do the Social Sciences Shape Corporate AntiDiscrimination Practice: The United States and France", Comparative Labor Law \& Policy Journal, vol. 23, pp. 829-863

Doytcheva, Milena. 2007. Une discrimination positive à la française? Ethnicité et territoire dans les politiques de la ville, Paris: La Découverte

Eliasoph, Nina. 1990. "Political Culture and the Presentation of a Political Self. A Study in the Spirit of Erving Goffman", Theory and Society, vol. 19, pp. 465-494

Eliasoph, Nina. 1996. "Making a Fragile Public: A Talk-Centered Study of Citizenship and Power", Sociological Theory, 14 (3), pp. 262-289

Eliasoph, Nina. 1999. "Everyday Racism in a Culture of Political Avoidance: Civil Society, Speech, and Taboo", Social Problems, 46 (4), pp. 479502

Essed, Philomena. 1991. Understanding Everyday Racism. An Interdisciplinary Theory, London: Sage

Farrell, Amy, Geoff Ward and Danielle Rousseau. 2009. "Race Effects of Representation among Federal Court Workers: Does Black Workforce Representation Reduce Sentencing Disparities?", Annals of the American Academy of Political and Social Science, vol. 623, pp. 121133

Fassin, Didier et Eric Fassin (ed.) 2006. De la question sociale à la question raciale? Représenter la société française, Paris : La Découverte

Fassin, Didier. 2006. "Nommer, interpréter. Le sens commun de la question raciale", Didier Fassin et Eric Fassin (ed.), De la question sociale à la question raciale? Représenter la société française, Paris : La Découverte, pp. 19-36

Fassin, Didier. 2011. La force de l'ordre. Une anthropologie de la police des quartiers, Paris : Seuil

Fassin, Eric. 2006. "Aveugles à la race ou au racisme? Une approche stratégique”, Didier Fassin et Eric Fassin (ed.), De la question sociale à la question raciale ? Représenter la société française, Paris : La Découverte, pp. 133-157

Favell, Adrian. 1988. Philosophies of Integration: Immigration and the Idea of Citizenship in France and Britain, London: Macmillan/New York: St.Martin's Press, 1998

Gerring, John. 2004. "What Is a Case Study and What Is It Good For?", American Political Science Review, 98 (2), pp. 341-“54. 
Glaser, Barney G. and Anselm L. Strauss. 1967, The discovery of grounded theory: strategies for qualitative research. Chicago: Aldine

Goffman, Erving. 1959. The Presentation of Self in Everyday Life, Garden City, NY: Anchor Books

Goffman, Erving. 1983. "The Interaction Order”, American Sociological Review, vol. 48, 1983, pp. 1-17

Hug, Pascal. 2000. "Les agents de sécurité noirs. Un exemple de discrimination dans le monde de la sécurité", Les cahiers de la sécurité intérieure, n40, pp. 93-118

Jackson, R. L. 2006. Scripting the Black Masculine Body: Identity, Discourse, and Racial Politics in Popular Media. Albany: SUNY Press

Keaton, Trica D. 2010. "The politics of race-blindness. (Anti-)Blackness and Category-Blindness in Contemporary France". Du Bois Review, 7 (1), pp. 103-131.

Kinder, D. and L. Sanders. 1996. Divided by Color : Racial Politics and Democratic Ideals, Chicago : University of Chicago Press

Kinder, Donald F. and David O. Sears. 1981. "Prejudice and Politics: Symbolic Racism versus Racial Threats to the Good Life", Journal of Personality and Social Psychology, vol. 40, pp. 414-431

Kirschenman, Joleen and Kathryn M. Neckerman. 1991. "We'd Love to Hire Them, But...': The Meaning of Race for Employers", in Christopher Jencks and Paul E. Peterson, eds., The Urban Underclass, Washington, D.C.: Brookings Institution, pp. 203-234

Kirszbaum, Thomas. 2004. "La discrimination positive territoriale : de l'égalité des chances à la mixité urbaine", Pouvoirs, n 111, p. 101-118

Krysan, Maria and Mick P. Couper. 2003. "Race in the Live and the Virtual Interview: Racial Deference, Social Desirability, and Activation Effects in Attitude Surveys", Social Psychology Quarterly, 66 (4), pp. 364-383

Lagrange, Hugues. 2006. "Autopsie d'une vague d'émeutes", in H. Lagrange and M. Oberti (ed.), Emeutes urbaines et protestations: une singularité française, Paris: Presses de Sciences Po, pp. 37-58

Lamont, Michèle and Crystal Marie Fleming. 2005. "Everyday Antiracism. Competence and Religion in the Cultural Repertoire of the African American Elite", Du Bois Review, 2:1 (2005) 29-43.

Lamont, Michèle and Sada Aksartova. 2002. "Ordinary Cosmopolitanisms. Strategies for Bridging Racial Boundaries among Working-class Men”, Theory, Culture \& Society, 19 (4), 2002, pp. 1-25

Lee, Jennifer. 2002. "From Civil Relations to Racial Conflict: MerchantCustomer. Interactions in Urban America", American Sociological Review, 67 (1), pp. 77-98

Lewis, Amanda E., Mark Chesler and Tyrone A. Forman. 2000. "The Impact of 'Colorblind' Ideologies on Students of Color: Intergroup Relations at 
a Predominantly White University", Journal of Negro Education, 69 (1/2), pp. 74-91

Lin, Ann Chih. 1998. "Bridging Positivist and Interpretivist Approaches to Qualitative Methods", Policy Studies Journal, 26 (1), pp. 162-180.

Macé, Éric. 1999. 'Les violences dites 'urbaines' et la ville : du désordre public au conflit dans l'espace public", Annales de la recherche urbaine, $\mathrm{n}^{\circ}$ 83-84, pp. 59-64

May, Ruben A. Buford. 2001. Talking at Trena's. Everyday Conversations at an African American Tavern, New York: NYU Press

McDermott, Monica. 2006. Working-class White. The Making and Unmaking of Race Relations, Berkeley: University of California Press

Myers, Kristen and Passion Williamson. 2001. "Race Talk: The Perpetuation of Racism Through Private Discourse", Race \& Society, vol. 4, pp. 3-26

Ndiaye, P. 2008. La condition noire: essai sur une minorité française. Paris : Calmann-Lévy

Open Society Institute. 2009, Profiling Minorities: A Study of Stop-and-Search Practices in Paris, Open Society Justice Initiative, http://www.opensocietyfoundations.org/sites/default/files/search_2009 0630.Web.pdf

Pager, Devah and Diana Karafin. 2009. "Bayesian Bigot? Statistical Discrimination, Stereotypes, and Employer Decision-Making”, Annals of the American Academy of Political and Social Sciences, n621(January), pp. 70-93

Pager, Devah and Lincoln Quillian. 2005. "Walking the Talk? What Employers Say Versus What They Do", American Sociological Review, 70 (3), pp. $355-380$

Pager, Devah et Hana Shepherd. 2008. "The Sociology of Discrimination : Racial Discrimination in Employment, Housing, Credit, and Consumer Markets", Annual Review of Sociology, vol. 34, pp. 181-209

Pager, Devah. 2008. "The Republican Ideal? Ethnic Minorities and the Criminal Justice System in Contemporary France", Punishment and Society, 10(4), pp. 375-400

Phillips, Derek L. and Kevin J. Clancy. 1972. "Some Effects of "Social Desirability" in Survey Studies", American Journal of Sociology, 77 (5), pp. 921-940

Picca, Leslie Houts and Joe R. Feagin. 2007. Two-Faced Racism: Whites in the Backstage and Frontstage, New York: Routledge

Pollock, Mica. 2004. Colormute. Race Talk Dilemmas in an American School, Princeton, NJ: Princeton University Press

Portes, Alejandro, Min Zhou. 1993. "The New Second Generation: Segmented Assimilation and its Variants", Annals of the American Academy of Political and Social Science, 530 (1), pp. 74-96 
Pringle, Colombe. 2000. "Lacoste victime de sa popularité", L'Express, June $1^{\text {st }}$, 2000, retrieved June $1^{\text {st }} 2012$,

http://www.lexpress.fr/informations/lacoste-victime-de-sapopularite $638485 . \mathrm{html}$

Quillian, Lincoln. 2006. "New approaches to Understanding Racial Prejudice and Discimination”, Annual Review of Sociology, vol. 32, pp. 299-328

Sabbagh, Daniel. 2011, "Affirmative Action: The U.S. Experience in Comparative Perspective", Daedalus, 140 (2), pp. 109-120

Schuman, Howard, Charlotte Steeh, Lawrence Bobo, and Maria Krysan. 1997. Racial Attitudes in America: Trends and Interpretations. $2^{\text {nd }}$ ed. Cambridge, MA: Harvard University Press

Sears, David O. 1996. "Presidential Address: reflections on the Politics of Multiculturalism in American Society”, Political Psychology, 17 (3)

Skrentny, John D. 1996, The Ironies of Affirmative Action: Politics, Culture, and Justice in America, Chicago: University of Chicago Press

Tonry, Michael. 1995. Malign Neglect. Race, Crime, and Punishment in America, Oxford : Oxford University Press

Tribalat, Michèle. 2004. "Une estimation des populations d'origine étrangère en France en 1999”, Populations, 59 (1), pp. 51-82

Unnever, James D. and Shaun L. Gabbidon. 2011. A Theory of African-American Offending. Race, Racism and Crime, New York and London: Routledge, 2011

Wacquant Loic J.D. 1997. "For an Analytic of Racial Domination", Political Power and Social Theory, vol. 11, pp. 221-234

Waddington, D., F. Jobard and M. King. (eds.). 2009. Rioting in the UK and France: A Comparative Analysis, Devon : Willan Publishing

Waldinger, Roger. 1996. Still the Promised City? New Immigrants and AfricanAmericans in Post-Industrial New York, Cambridge, MA: Harvard University Press

Ward, Geoff. 2006. "Race and the Justice Workforce: A System Perspective." in R. Peterson, L. Krivo, and J. Hagan (eds.), The Many Colors of Crime: Inequalities of Race, Ethnicity and Crime in America, New York: NYU Press, pp. 67-87

Weitzer, Ronald and Steven A. Tuch. 2005. "Racially biased policing: Determinants of citizen perceptions", Social Forces, vol. 83, pp. 10091030

Winant, Howard. 2000. "Race and Race Theory", Annual Review of Sociology, 2000, pp. 169-185

Winant, Howard. 2007. "The Dark Side of the Force: One Hundred Years of the Sociology of Race", in Craig Calhoun, (ed.), Sociology in America: The ASA Centennial History, Chicago: University of Chicago Press, 2007 
Young, Alford A. 2004. The Minds of Marginalized Black Men: Making Sense of Mobility, Opportunity, and Future Life Chances. Princeton, NJ:

Princeton University Press, 2004

Zamudio, Margaret M. and Francisco Rios. 2006. "From Traditional Racism to

Liberal racism: Living Racism in the Everyday", Sociological

Perspectives, 49 (4), pp. 483-501

\footnotetext{
${ }^{\mathrm{i}}$ In the article, I will speak of "minority youth", unless the specific ethnicity of the people is meaningful, in which case I will speak of "Arabs" and "Blacks" to avoid euphemisms or technical terms. I translate jeune de banlieue as "urban youth" though, literally, jeune de banlieue means "suburban youth" because, in France, suburbs refer to poor, minority spaces. "Urban youth" thus best conveys both the spatial connotation and the American intuitive meaning for "poor and minority".

${ }^{\text {ii }}$ Quillian (2006:301) writes for instance that "racist is used rather than prejudiced or discriminatory to signal the speaker's unambiguous condemnation of the belief or practice in question". Lee (2002) and Pager and Karafin (2009) do not even use the word "racism", and Pager and Quillian's (2005) use it only once in their article.

iii Hoodlum (racaille) is a controversial word. It may be a racist slur referring to minority youth, implying that minority youth are delinquents. It may also be a way, especially for young people, to make a distinction between delinquent urban youth (hoodlums) and "decent" urban youth. It the latter sense, "hoodlum" is used as a colorblind term to disconnect hoodlumism from ethnicity, implying that hoodlumism is a lifestyle, not an ethnic attribute.
} 